\title{
Representation of human rights across different national contexts: the role of democratic and non-democratic populations and governments
}

\author{
CHRISTIAN STAERKLÉ ${ }^{1 *}$, \\ ALAIN CLÉMENCE ${ }^{2}$ and WILLEM DOISE ${ }^{1}$ \\ ${ }^{1}$ Faculty of Psychology, University of Geneva, \\ Switzerland \\ ${ }^{2}$ University of Lausanne, Switzerland
}

\section{Abstract}

This research studied judgements and inferences on human rights across democratic and non-democratic national contexts. It is argued that when judging different countries, lay perceivers make use of representations of the country's inhabitants. Stereotypically democratic and non-democratic characteristics of national populations are employed as a basis of political judgements, especially in democratic contexts. In three studies the bases of representations of human rights' respect and violations are investigated. In the first study 76 subjects drew inferences on the human rights situation from formal descriptions of countries. These are either described with a type of government (democratic or authoritarian) or with national characteristics associated to the population (orderly and discussing or disorderly and clashing). In Study 2 (117 subjects), political and population information are crossed. In Study 3, 126 subjects evaluated the responsibility of the government and of the inhabitants in explaining the general situation in two positively and two negatively described national contexts. The results show the pervasive impact of population information on political judgements. Moreover members of non-democratic countries are viewed as accepting more human rights violations than members of democratic countries. This attitude inference is used by people to account for violations of human rights. Results are discussed in terms of common sense transformation of classical political theories which are grounded on universalism and essentialism. It is suggested that philosophical knowledge, much like

\footnotetext{
*Address for correspondence: Christian Staerklé, Faculty of Psychology, University of Geneva, 9, rte de Drize, CH-1227 Carouge, Switzerland. Tel: +41 2234392 43. Fax: +41 2230020 64. E-mail: staerkle@ibm.unige.ch.

Partial results of Studies 1 and 2 were presented at the XXVI International Congress of Psychology in Montreal, Canada, August 1996. Studies 1 and 2 were supported by grant No. 1114-037604.93 from the Swiss National Science Foundation. We are grateful to Martha Augoustinos, Fabrizio Butera, Margarita Sanchez-Mazas and two anonymous reviewers for their helpful comments and suggestions on an earlier draft of this paper and to Eva Green for her assistance in conducting Study 3.
} 
scientific knowledge, is altered when penetrating common sense, thereby receiving specific social and ideological functions. (C) 1998 John Wiley \& Sons, Ltd.

\section{INTRODUCTION}

In the coming era of globalization people will frequently be asked to judge the political situation in different national contexts. Do people base their judgements merely on their representation of a country's political system or also on a representation of the characteristics of its inhabitants? Furthermore, how do these representations affect lay perceiver's explanations of political situations? Our studies address these two questions by examining how people infer, on the one hand, human rights' respect and violations and, on the other hand, inhabitants' attitudes towards human rights violations in various national contexts defined by characteristics of their governments and their populations.

So far researchers in social psychology studying the issue of human rights have been mainly interested in individual differences in the value and attitude structure underlying human rights principles (Bond, 1988; Diaz-Veizadez, Widaman, Little, \& Gibbs, 1995; Stainton-Rogers \& Kitzinger, 1995), in the representation of human rights and their violations by subjects living in different national contexts (Clémence, Doise, De Rosa, \& Gonzalez, 1995; Doise, Spini, Jesuino, Ng, \& Emler, 1994) and in the use of the rights as a basis of moral and social judgement (Clémence \& Doise, 1995). Another line of research has dealt with embedding human rights in concrete situations. In a series of studies on the consistency of human rights' attitudes Moghaddam and Vuksanovic (1990) showed that people's judgements of events and situations involving human rights were dependent on the particular national context wherein human rights were evoked. In a first study subjects were asked to indicate their support for different human rights measures in Canada, the Soviet Union or the Third World. Results showed that their support is larger in the two latter contexts. In their second study various scenarios relating human rights' violations taking place either in Montreal, Moscow or New Delhi are proposed to the subjects. Subjects' support towards human rights ideas was stronger when the events took place in Moscow and New Delhi rather than in Montreal. The first aim of the present research is to propose a more general approach to such lay conceptions of human rights in democratic and non-democratic contexts. Secondly we will extend lay conceptions to lay explanations by examining the attitude towards human rights people attribute to members of different national populations.

Human rights were created in order to define the relationship between national institutions - usually the government - and the inhabitants of any country in the world. As such they are supposed to guarantee basic freedom rights for individuals and to protect them from arbitrary and unfair treatments. René Cassin (quoted by Madiot, 1991), one of the authors of the Universal Declaration of Human Rights, stated: 'The Universal Declaration of Human Rights defines the limits that the omnipotent machine of the State has to take care not to exceed in its relations with those who are subject to it' (our translation). Yet, experts from different scientific disciplines have debated the underlying concept of universality of human rights ever since they were proclaimed in 1948 by the United Nations Organization. These 
controversies about the potential universalism of human rights, massive media diffusion as well as their political use have contributed to the emergence of human rights as part of a widely shared knowledge, as part of our common sense. Moreover, throughout the last 50 years, the notion of human rights has constantly been internationalized (Madiot, 1991). Through this process people in the western world are frequently confronted with human rights issues taking place in unfamiliar and remote parts of the world of which they possess only poor knowledge.

\section{Transforming and Sharing Political Theories}

Human rights are based on political theories. Classical liberal political theory on which human rights are based has argued that a specific type of citizen, sharing attributes such as independence, sense of responsibility and rationality, is essential for the functioning of a democratic society. These features thus became the necessary foundations of the principles underlying human rights, among them equality, freedom and political participation (see Benhabib, 1996). These are considered universal characteristics of the human nature. To the extent that members of democratic populations are seen as sharing these stable and profound characteristics, classical political theory is based on a essentialistic view of democratic citizens.

However, much like scientific information, philosophical knowledge is transformed when it penetrates different social contexts. Social representations research shows that people transform a general and abstract knowledge into concrete or symbolic images, figures or metaphors (Doise, Clémence, \& Lorenzi-Cioldi, 1993; Moscovici, 1976; Moscovici \& Hewstone, 1984; Wagner, Elejabarrieta, \& Lahnsteiner, 1995). This objectification process operates through everyday communication and gives rise to a dominant way of thinking about a social object. Political philosophy, even when it is not explicitly declared as such, is frequently present in the media and everyday discourse (Billig, 1991). Political information is often discussed by the media and in everyday communication in a manner that can be traced back to ideas derived from classical philosophical theories. This is the case when people put the blame of unemployment on personality attributes of the unemployed rather than on structural economic reasons or when they claim that "This population is "not yet ready" for a democratic society'.

In our view people share lay political theories that help them understand and make sense of complex issues related to human rights and other political situations occurring in their own as well as in other countries. The essentialistic stance of liberal political philosophy has permeated common sense. It has become part of the ideological heritage of western countries (Augoustinos \& Walker, 1995). Human rights are closely associated to this western value system.

\section{Giving a Concrete Shape to Abstract Representations of Governments and Populations}

Our first conjecture is that people judge and explain human rights situations by establishing links between the representations of the population and the government of a given country. People do not view government and population as two 
independent entities, rather they perceive them as one mirroring the other. (Western) politicians may involuntarily illustrate the common sense assumption of an association between the government and its population by claiming that 'A population has the government it deserves'. A similar conception of political justice thinking can be applied to unfavourably as well as favourably perceived countries, although different weights may be given to each of the two categories. The studies of Allison and Messick $(1985,1987)$ on the group attribution phenomenon offer clear support for the assumption of lay inferences of national group members' attitudes and characteristics based on a decision of the group's leader.

In the realm of political judgements the objectification process transforms general and abstract ideas circulating on democratic and non-democratic states into political lay representations. If people establish an association between a population and a government, then they should objectify and make real general descriptions of a government as well as of a population. An easy way to give a figurative shape to a formal description of a democratic or a non-democratic government is to replace it by some well-known and specific country. In this domain, people share common reference marks helping them to draw a political map of the world (see Wish, Deutsch, $\&$ Biener, 1970). Western countries like France or the U.S.A. are seen as prototypical democracies, whereas strongly mediatized countries like China or Iran are classified as typical non-democratic countries. We then expect that people objectify a formal description of a population in a similar manner. A pacifist and discussing population should be associated with western democratic countries whereas an unruly and quarrelsome population should be associated with authoritarian countries. Checking this objectification process is the first aim of the present research.

\section{Completing Lacking Information about Human Rights by Lay Political Theories}

With some justification, interest is centred on human rights' violations rather than on their respect. As a consequence, people are frequently informed about human rights violations in countries often unfamiliar to them. This unfamiliarity pertains as much to governments as to populations. Lay perceivers may complete lacking knowledge about the underlying reasons of particular human rights situations by having recourse to general and simplified representations of democratic and non-democratic countries. Even if they have never been directly confronted with members of these little known populations, people may feel that they know something about the inhabitants of a given national state. By using common ideas circulating on a country or on its inhabitants, people may give meaning to real world situations and thus compensate for incomplete or lacking information. The scarce information people dispose of is completed by integration in already familiar knowledge (Moscovici, 1984). New information becomes associated with prior knowledge and is no longer dependent on observable behaviours, events or outcomes: people do not need to perceive group members' behaviours in order to proceed to judgements, they rather represent them by means of socially shared knowledge. Group perception thus becomes group representation.

In an expert view, the explanation of the most currently denounced human rights violations - arbitrary imprisonment, torture, limitations of freedom of expression - is placed on governmental institutions (see for instance Humana, 1992). The population 
is seen as the victim of a government that violates human rights or that does not guarantee protection against these violations. This expert view is consistent with the principles of the Universal Declaration of Human Rights. Yet we contend that lay perceivers also take into account psychological features of the population in order to judge human rights issues. Inferential thoughts like 'Given the character of the inhabitants, it's hardly surprising that human rights are violated' may be used to account for a given human rights situation in a national context.

Then, like experts, people should be able to infer the human rights situation on the basis of a description of a government. But, more importantly and contrary to experts, people should also rely on stereotypical descriptions of a population in order to represent the human rights situation in a given national context. The second aim of the research was to test this hypothesis.

\section{Attitude and Responsibility Attribution for Favourable and Unfavourable Situations}

Most of the studies carried out on explanations of societal events such as poverty or inequality have been limited to the explanation of unfavourable phenomena within a given society (Feagin, 1972; Guimond, Begin, \& Palmer, 1989; Hewstone, 1989). Much less attention has been devoted to lay explanations of favourable living conditions.

People supposedly consider that 'typical' human rights violations rarely occur in democracies. If people rely on liberal political theories, then they should account for the perceived respect of the rights not only by invoking political and ideological characteristics of a democratic government, but also by attributing stereotypically democratic characteristics to members of a rights-respecting country. Hence, members of democratic populations should be viewed as being different from those living in non-democratic states on a dimension of political involvement. Because democratic citizens themselves are part of the lay definition of human rights respect, they should be perceived as being more supportive of human rights than non-democratic populations. We then expect that subjects of western countries should consider that perceived attitudes towards human rights of members of a national population are closely linked to the degree of perceived human rights violations in this national context. That is, the more members of a population suffer from human rights violations, the more they will be seen as accepting these violations, thereby originating them at least partly. The inhabitants of a rights-respecting country, however, should be considered to accept these violations less.

Moreover, if lay perceivers infer attitudes of the inhabitants on the basis of political information, then responsibility of the human rights situation should be, to some extent, attributed to the inhabitants themselves. In other words, if members of democratic populations are perceived as being opposed to violations, then they should be considered more responsible for the respect of human rights than the government. This hypothesis will also be tested in this research.

\section{OVERVIEW OF THE STUDIES}

In the present studies, subjects were invited to read a description of a national state with either a democratic or an authoritarian government and/or a positively or 
negatively connoted national character associated to the population. In Study 1 only a description of a government or a national character was used. Study 2 combined both descriptions, so that the weight attributed by subjects to each of the categories could be investigated. Study 3 again used the single descriptions.

In all the three studies, the first task consisted of giving up to three names of countries corresponding to the description. The general procedure thus induced an objectification process by requesting subjects to transform an abstract representation of a national state, based on minimal political and/or population information, into a concrete representation of a country, including their populations and their governments.

In order to enable comparisons between inferences on human rights situation based either on a description of a government and/or a national character, subjects' second task was to estimate the degree of human rights respect in the context corresponding to its description. Finally, subjects were requested to indicate the proportion of the population who found a series of human rights' violations unacceptable. This measure was used to assert the perceived proportion of the population accepting different human rights violations, thus blaming the inhabitants for the violations.

Study 3 was designed to specify the degree of responsibility attributed to the inhabitants and to the political system in the explanation of the human rights situation in a country.

\section{STUDY 1}

The aim of Study 1 was to show that a minimal description of a government and of a population is easily translated into a specific country. A democratic description of a government and a positive description of a population, on the one hand, and an authoritarian description of a government and a negative description of a population, on the other hand, should evoke the same countries for subjects. According to the second hypothesis subjects should proceed to similar inferences on the human rights situation when the description of the country is based either on the population or on the government. Subjects should not only perceive more violations in a national authoritarian system than in a democratic one, but also when the population is negatively rather than positively described. The third hypothesis states that subjects should perceive a relationship between the inferred attitude of the population and perceived degree of human rights violations: a greater proportion of members of the national population should be viewed as accepting infringements of human rights, not only when the population is negatively defined, but also when the government is presented as authoritarian.

\section{Method}

\section{Subjects}

Seventy-six French-speaking Swiss college students participated in the study; mean age was between 17 and 18 years. Subjects were randomly assigned to the four experimental conditions. 


\section{Stimulus Materials and Procedure}

The study was carried out in December 1994. A computerized questionnaire was designed by Authorware Professional Software. Subjects were informed that they were participating in a study on human rights. All information necessary to complete the questionnaire was provided on the screen. Subjects decided for themselves the pace of display. The questionnaire started with two questions unrelated to human rights in order to allow subjects to become familiarized with the computerized procedure.

The vignette method was used to create the four experimental conditions. Each subject read a one-paragraph vignette describing the government (democratic or authoritarian) or the population (orderly and discussing or disorderly and clashing) of a fictitious country. Democratic (and Authoritarian) conditions read as follows: 'Think of a country where political, economic and military power are held by different (the same) persons, a country where the government takes its decisions by consulting the population and its representatives (without consulting either the population or its representatives)' and Discussion (and Clashes) conditions read as follows: 'Think of a country in which the inhabitants are quite orderly (disorderly) and resolve their conflicts often by discussion (clashes)'. For convenience, we will refer to these descriptions also as positive (Democratic and Discussion) and negative conditions (Authoritarian and Clashes). The text was kept visible throughout the entire experiment.

Subjects were first asked to give up to three names of countries corresponding to the description.

Secondly they evaluated to what extent freedom of expression and freedom of religion, two of the most widely known human rights, at least in Geneva (Doise \& Herrera, 1994), were respected in the country. They had to click a number on the screen on a 1-item rating scale that ranged from 1 (not at all) to 7 (absolutely). In order to enhance stability of the measure of perceived human rights violation and respect, subjects were then asked to evaluate the difficulty in exercising several actions guaranteed by human rights. These included defence by a lawyer, freedom of settlement, political asylum, foundation of a company, freedom of expression, membership in a trade union, protection against aggression and health care. Again, scales ranging from 1 (difficult) to 7 (easy) were used.

Finally subjects were asked to evaluate the percentage of the population of the country rejecting different human rights violations. Items included work by children, imprisonment of persons refusing to serve in the army, expulsion of foreigners without trial, school ban for clandestine children, banning political parties and demonstrations, censorship of TV programmes, mistreatment of prisoners, death sentence and limitation of the number of children in a family. Subjects responded by means of scales ranging from 1 ( 0 per cent) to 6 (100 per cent).

\section{Results}

\section{Country Quotations}

The first issue concerns the countries associated with the formal description of the government or the population. Each subject could give up to three names of different countries. Table 1 shows the countries associated with the description. 
Table 1. Countries associated (\%) with descriptions, according to the experimental conditions for Study 1

\begin{tabular}{lcccc}
\hline & \multicolumn{2}{c}{ Positive } & \multicolumn{2}{c}{ Negative } \\
& $\begin{array}{l}\text { Democratic } \\
\text { government }\end{array}$ & $\begin{array}{c}\text { Discussing } \\
\text { population }\end{array}$ & $\begin{array}{c}\text { Authoritarian } \\
\text { government }\end{array}$ & $\begin{array}{c}\text { Clashing } \\
\text { population }\end{array}$ \\
\hline Switzerland & 83 & 83 & & \\
France & 72 & 55 & & 4 \\
Germany & 44 & 27 & & 4 \\
Other Western Countries & 50 & 50 & 18 & 75 \\
Ex-Yugoslavia & & & 43 & 33 \\
Russia & & & 43 & 4 \\
Cuba & 5 & 11 & 43 & 54 \\
African Countries & & 5 & 12 & 70 \\
Middle Eastern Countries & & 11 & 12 & 25 \\
Other Asian Countries & & & 6 & 8 \\
East European Countries & 2.6 & 2.6 & 2.1 & 2.8 \\
South American Countries & & & 16 & 24 \\
Mean frequency of evoked & 18 & 18 & 16 & \\
$\quad$ countries & & & & \\
Number of subjects & & & & \\
\hline
\end{tabular}

Note. Percentages are calculated on the subjects. Other Western Countries include, in decreasing frequency, U.S.A., United Kingdom, Andorra, Canada, Italy, Portugal, Spain, and Sweden; African Countries: Algeria, Rwanda, South Africa, and Somalia; Middle Eastern Countries: Iraq, Israel, Iran, Afghanistan, Palestine, Chechnya, Saudi Arabia, and Turkey; Other Asian Countries: China, Cambodia, and Vietnam; East European Countries: Romania, Slovak and Czech Republics; South American Countries: Colombia and Peru.

As expected, subjects objectified countries in a similar way on the basis of a formal description of a democratic government and of a discussing and orderly population. In these two conditions they generally quoted identical western European countries. Between the authoritarian and clashing conditions however some differences appear: communist or ex-communist countries are frequently associated with an authoritarian government and countries in a state of (civil) conflict are associated with disorderly and clashing populations.

\section{Estimation of Human Rights Respect}

The second issue concerned the inferences on human rights respect in the country. Reliability analysis of the two items measuring respect for freedom of expression and religion gives a Cronbach's alpha of 0.86 . A 2 (positive versus negative conditions) $\times 2$ (government versus inhabitants) ANOVA was carried out on the mean score. Only the main effect of positivity was significant, $F(1,72)=160.8, p<0.001$, indicating that in the two positive national contexts human rights are more respected than in the two negative contexts (Table 2).

Eight items describing actions guaranteed by human rights were used as another measure of perceived human rights respect. Analysis shows high reliability (Cronbach's alpha $=0.93$ ). The same analysis as was performed previously on the mean score was used. Positive conditions were opposed to negative conditions, 
Table 2. Mean scores of estimation of human rights' respect and of population attitude inference according to the experimental conditions for Study 1

\begin{tabular}{|c|c|c|c|c|c|c|c|c|}
\hline & \multicolumn{4}{|c|}{ Positive } & \multicolumn{4}{|c|}{ Negative } \\
\hline & \multicolumn{2}{|c|}{$\begin{array}{l}\text { Democratic } \\
\text { government }\end{array}$} & \multicolumn{2}{|c|}{$\begin{array}{l}\text { Discussing } \\
\text { population }\end{array}$} & \multicolumn{2}{|c|}{$\begin{array}{c}\text { Authoritarian } \\
\text { government }\end{array}$} & \multicolumn{2}{|c|}{$\begin{array}{l}\text { Clashing } \\
\text { population }\end{array}$} \\
\hline & $M$ & S.D. & $M$ & S.D. & $M$ & S.D. & $M$ & S.D. \\
\hline Respect of rights ${ }^{\mathrm{a}}$ & $5.03_{\mathrm{a}}$ & 1.02 & $5.09 \mathrm{a}$ & 1.60 & $1.83_{\mathrm{b}}$ & 1.08 & $1.79_{\mathrm{b}}$ & 0.71 \\
\hline Exercise of rights ${ }^{\mathrm{a}}$ & $4.92^{\mathrm{a}}$ & 0.90 & $5.01_{\mathrm{a}}^{\mathrm{a}}$ & 1.12 & 2.24 & 0.74 & $2.24_{\mathrm{b}}$ & 0.73 \\
\hline $\begin{array}{l}\text { Population attitude } \\
\text { inference }\end{array}$ & $4.06^{\mathrm{a}}$ & 0.63 & $4.19^{\mathrm{a}}$ & 0.55 & $3.62_{\mathrm{b}}$ & 0.86 & $3.71^{\circ}$ & 0.74 \\
\hline
\end{tabular}

Note. ${ }^{\mathrm{a}} 1$, rights violated; 7 , rights respected. ${ }^{\mathrm{b}} 1,0$ per cent of the population find human rights violations unacceptable; 6,100 per cent find human rights violations unacceptable. Means in the same row with different subscripts differ significantly at $p<0.05$ (Tukey test).

$F(1,72)=182.9, p<0.001$. Neither the difference between government and inhabitants conditions, nor the interaction effect were significant (Table 2). These results show that subjects believe that it is more difficult to exercise different actions guaranteed by the Universal Declaration in the two negative experimental conditions and are thus consistent with our hypothesis.

\section{Population Attitude Inference}

The last prediction concerns subjects' inferences of the attitude of the population towards different human rights' violations. For countries governed by an authoritarian regime and inhabited by disorderly and clashing people, subjects should perceive less opposition by the inhabitants to different human rights' violations than for countries governed by a democratic system or inhabited by orderly and discussing people. The analysis was performed on the mean score of the 10 items describing human rights' infringements (Cronbach's alpha $=0.79$ ). Again, only the main effect of positivity is significant, $F(1,72)=7.6, p<0.01$. However, a post-hoc comparison of the means (Tukey range test) reveals that the difference is only significant between the discussing population and the authoritarian government conditions (Table 2).

\section{Discussion}

Study 1 provides evidence for the hypothesis that people evaluate the human rights situation in a country not only on the basis of the type of government, but also on the basis of the character of the inhabitants. Inferences on human rights' respect and violation were similar in countries described either with a democratic type of government and discussing inhabitants or with an authoritarian government and a clashing population. No differences were found within the two positive and the two negative conditions. In the democratic and orderly conditions this result may be due to the fact that subjects mostly think of the same countries. However, in the authoritarian and disorderly conditions subjects only partially identify the same countries, yet inferences are identical. This finding suggests that similar representations are activated when subjects are confronted with a description of an authoritarian 
regime and a negative stereotype of a population. Indeed, both measures of human rights' respect led to these results. Moreover, subjects believed that members of a discussing population, associated with a democratic western country, reject human rights' violations more than members of a population governed by an authoritarian political system. This last result provides evidence for the hypothesis that people consider the inhabitants as at least partially responsible, along with the government, for the human rights situations in a country. In order to examine how people weight the political system and the character of the population in their judgements of the human rights situation, the two inferential descriptions were crossed in a second study.

\section{STUDY 2}

The results of Study 1 do not define the relative importance of each of the two categories as a basis for human rights' judgements. The findings of the first study, however, suggest that the combination of the two factors leads to two expectedly compatible (Democratic/Discussing and Authoritarian/Clashing) and two expectedly incompatible experimental conditions (Democratic/Clashing and Authoritarian/ Discussing). Two alternative hypotheses imply an interaction effect: on the one hand people may reason in terms of positivity and negativity. Following the literature on the positive-negative asymmetry in social judgements (Dreben, Fiske, \& Hastie, 1979; Van der Pligt \& Eiser, 1980; Martijn, Spears, Van der Pligt, \& Jakobs, 1992; Skowronski \& Carlston, 1992), we could predict that subjects will use the negative factor more than the positive one. This assumption is supported by the work of Skowronski and Carlston (1987), proposing that in the domain of morality, as opposed to the domain of ability, negative information is more diagnostic. It will therefore receive more weight and result in a negativity effect.

On the other hand subjects may give more weight either to the information related to the political system or to the character of the population. In the first case, corresponding to an expert view, the two democratic conditions should be opposed to the two authoritarian conditions and in the latter one the two discussing conditions should be opposed to the two clashing conditions. But the results of Study 1 show that the population character information is sufficient to allow a judgement of the human rights situation in a given national context. Consequently the first predictions derived from the judgmental positive-negative asymmetry are more consistent with the hypothesis concerning the pervasive impact of population characteristics on judgements of democratic and non-democratic countries.

\section{Method}

\section{Subjects}

One hundred and seventeen French-speaking Swiss college students participated in the study; the mean age was 17 years. Subjects were randomly assigned to the four experimental conditions. 


\section{Stimulus Materials and Procedure}

The study was carried out in January 1995. A traditional paper and pencil questionnaire was used. Subjects read that they were participating in a study on human rights. The vignette method was again employed, each subject reading a two-paragraph vignette. The text was identical to the one used in Study 1, but political and population information were combined. Political information always preceded population information.

\section{Dependent Measures}

Measures were identical to those used in Study 1, that is: country quotations, estimation of the respect of freedom of expression and religion as well as of the difficulty in exercising actions guaranteed by human rights, and estimation of the proportion of the population finding the 10 human rights' violations unacceptable.

\section{Results}

\section{Country Quotations}

Again subjects were asked to indicate up to three countries corresponding to the description. Table 3 gives the proportions.

Table 3. Countries associated (\%) with descriptions, according to the experimental conditions for Study 2

\begin{tabular}{lcccc}
\hline & $\begin{array}{c}\text { Democratic } \\
\text { Discussing }\end{array}$ & $\begin{array}{c}\text { Democratic } \\
\text { Clashing }\end{array}$ & $\begin{array}{c}\text { Authoritarian } \\
\text { Discussing }\end{array}$ & $\begin{array}{c}\text { Authoritarian } \\
\text { Clashing }\end{array}$ \\
\hline Switzerland & 82 & 3 & 3 & \\
France & 39 & 7 & 3 & 3 \\
U.S.A. & 29 & 13 & 7 & 7 \\
Other Western Countries & 54 & 27 & 17 & 38 \\
Ex-Yugoslavia & & 23 & 7 & 45 \\
Rwanda & & 7 & 17 & 21 \\
Cuba & 4 & 7 & 17 & 10 \\
Russia & & 20 & 37 & 52 \\
Other African Countries & & 17 & 37 & 24 \\
Middle Eastern Countries & & 17 & 27 & 21 \\
South and Central & & 3 & 37 & 14 \\
$\quad$ American Countries & 4 & 10 & 17 & 10 \\
Other Asian Countries & 2.1 & 1.6 & 2.2 & 2.5 \\
East European Countries & & 30 & 30 & 29 \\
Mean frequency of evoked & 28 & & & \\
$\quad$ countries & & & & \\
Number of subjects & & & & \\
\hline
\end{tabular}

Note. Percentages are calculated on subjects. Other Western Countries include, in decreasing frequency, Italy, Germany, Ireland, Austria, Belgium, Norway, Canada, Greece, United Kingdom, and Vatican; African Countries: Algeria, South Africa, Somalia, Libya, Angola, Morocco, Zaire, Cameroon, and Senegal; Middle Eastern Countries: Iraq, Iran, Israel, Saudi Arabia, Turkey, Egypt, Kurdistan, Lebanon, and Palestine; Other Asian Countries: China, India, Indonesia, Japan, Korea (North and South), Myanmar, and Thailand; East European Countries: Romania, Poland, and Slovak Republic; South and Central American Countries: Colombia, Haiti, Chile, Brazil, and El Salvador. 
When a democratic type of government and a positive description of the inhabitants were combined, subjects almost exclusively thought of western democracies. Moreover the lowest quotation frequency in the Democratic/Clashing condition $(M=1.60)$ suggests that this combination is the most difficult one for subjects to associate to a 'real' country, whereas more countries are quoted in conditions Democratic/Discussing (2.11), Authoritarian/Discussing (2.23) and Authoritarian/ Clashing (2.45). This result shows that it was difficult for subjects to think of a democratic country inhabited by disorderly and clashing people.

\section{Estimation of Human Rights' Respect}

Reliability of the two items measuring respect of freedom of expression and religion was high (Cronbach's alpha $=0.91$ ), so that the analysis of variance could be performed on the mean score. Independent variables were type of government (Democratic versus Authoritarian) and national character (Discussing versus Clashing). Both variables exert a strong main effect: freedom of expression and religion are more respected in countries governed by democratic regimes, $F(1,113)=112.7, p<0.001$, and in countries inhabited by discussing people, $F(1,113)=44.4, p<0.001$. However, the interaction effect was also highly significant, $F(1,113)=37.6, p<0.001$. A post-hoc comparison of the means showed that respect of human rights was higher in the Democratic/Discussing condition than in the three other conditions and that the difference between discussing and clashing inhabitants occurred only in the democratic context (see Table 4).

Inner consistency of the eight items describing conditions guaranteed by human rights was high (Cronbach's alpha $=0.93$ ). ANOVA on the mean score gave a significant difference between democratic and authoritarian countries, $F(1,107)=112.1$, $p<0.001$, and between discussing and clashing populations, $F(1,107)=38.0$, $p<0.001$. The interaction effect was again significant, $F(1,107)=11.6, p<0.001$, revealing the same pattern of differences as described above (Table 4).

\section{Population Attitude Inference}

The same procedure was adopted with the 10 items measuring the proportion of the population opposed to different violations (Cronbach's alpha $=0.75$ ). The two main

Table 4. Mean scores of estimation of human rights' respect and of population attitude inference according to the experimental conditions for Study 2

\begin{tabular}{|c|c|c|c|c|c|c|c|c|}
\hline & \multicolumn{2}{|c|}{$\begin{array}{l}\text { Democratic } \\
\text { Discussing }\end{array}$} & \multicolumn{2}{|c|}{$\begin{array}{l}\text { Democratic } \\
\text { Clashing }\end{array}$} & \multicolumn{2}{|c|}{$\begin{array}{l}\text { Authoritarian } \\
\text { Discussing }\end{array}$} & \multicolumn{2}{|c|}{$\begin{array}{c}\text { Authoritarian } \\
\text { Clashing }\end{array}$} \\
\hline & $M$ & S.D. & $M$ & S.D. & $M$ & S.D. & $M$ & S.D. \\
\hline Respect of rights ${ }^{\mathrm{a}}$ & $5.77_{\mathrm{a}}$ & 1.29 & $2.80_{\mathrm{b}}$ & 1.65 & $1.88_{\mathrm{c}}$ & 0.84 & $1.76_{\mathrm{c}}$ & 1.09 \\
\hline Exercise of rights ${ }^{\mathrm{a}}$ & $5.41_{\mathrm{a}}^{\mathrm{a}}$ & 0.97 & $3.52_{\mathrm{b}}^{\mathrm{b}}$ & 1.42 & $2.65_{\mathrm{c}}^{\mathrm{c}}$ & 0.92 & $2.11_{\mathrm{c}}^{\mathrm{c}}$ & 0.65 \\
\hline $\begin{array}{l}\text { Population attitude } \\
\text { inference }\end{array}$ & $4.08_{\mathrm{a}}^{\mathrm{a}}$ & 0.44 & $3.55_{\mathrm{b}}^{\circ}$ & 0.67 & $3.44_{b}$ & 0.72 & $3.43_{\mathrm{b}}$ & 0.75 \\
\hline
\end{tabular}

Note. ${ }^{\mathrm{a}} 1$, rights violated; 7 , rights respected. ${ }^{\mathrm{b}} 1,0$ per cent of the population find human rights violations unacceptable; 6,100 per cent find human rights violations unacceptable. Means in the same row with different subscripts differ significantly at $p<0.05$ (Tukey test). 
effects are significant (type of government: $F(1,113)=9.7, p<0.01$ and type of population: $F(1,113)=4.7, p<0.05)$. The interaction effect between type of government and national character was also significant, $F(1,113)=4.6, p<0.05$. Discussing inhabitants in a democratic country were perceived as being more opposed to human rights' violations than inhabitants in the other three contexts (Table 4).

\section{Discussion}

All three measures reveal a similar pattern of results: the Democratic/Discussing condition was always opposed to the other three conditions and no difference was found between the two authoritarian conditions. Moreover, the condition Democratic/ Clashing was different from the other three conditions for the measures of human rights' respect. This latter result suggests that subjects expected an orderly and discussing population in a democracy: the country was seen as respecting human rights less, when the description of a democracy was accompanied by a negative description of the population. The high variance of the Democratic/Clashing condition substantiates this finding, suggesting that some of the subjects based their judgements more on the type of government, the other part relying more on the description of the population.

In the case of an authoritarian state subjects recognized the responsibility of the government for human rights' violations, considering that the difference within the two authoritarian conditions was not significant. This result suggests that in negatively perceived states the government played a more important role in the responsibility for human rights' violations, than in positively perceived countries. Here, the representations of the population and of the government were equally important.

Results thus revealed subjects' belief that foremost orderly and discussing people living in a democracy are actively opposed to human rights' violations perpetrated by governmental institutions. The perceived respect of human rights in the Democratic/ Discussing context suggests therefore that respect of human rights is viewed as being closely related to the political involvement of the inhabitants. Indeed, additional analysis revealed that in the two democratic conditions perceived political opposition and both estimated respect of freedom of expression and religion $(r=0.44, p<0.001)$ and perceived difficulty in exercising actions guaranteed by human rights $(r=0.49$, $p<0.001)$ were correlated. No significant relationship was found in the two totalitarian conditions ( $r=-0.12$, n.s. and $r=-0.02$, n.s. respectively).

The results support both hypotheses. First it appears that subjects reason in terms of negativity by setting positive descriptions of a government or a population against negative ones. However, they give more weight to the political information when the government is negatively described. Thus, the two hypotheses must be articulated. Subjects seem to differentiate democratic and non-democratic political systems first and then continue by differentiating the positive or negative character of the population, but only for a positively perceived political system. In other words, the representation of respect of human rights depends on the character of the inhabitants in a democratic country and on the political system in an authoritarian national context.

One could argue, however, that these data demonstrate an ingroup/outgroup effect by stressing that subjects (living in a Western European country) judged more positively a population they belong to than another one. Such an interpretation 
appears to be implausible for three reasons. First, no intergroup comparison was manipulated in the study. Secondly, contrary to the Moghaddam and Vuksanovic study, subjects are not induced to use human rights' judgements aimed at preserving or enhancing their ingroup. The third argument refers to the evaluative connotation of democracy, consensually considered as positive. It is indeed difficult to imagine that a non-democratic country could be perceived more positively than a democratic one. This assumption is illustrated by the fact that governments officially considered as non-democratic often claim to be democratic or invoke other good reasons for explaining their political system. The same is true for people arguing in favour of a non-democratic country, be it their own or another one.

Likewise one could think that subjects associate their own country with a democratic country in order to give a favourable impression of it. But this is not the question investigated here. We are rather interested in the way subjects infer characteristics of a population on the basis of a (positive) representation of a democratic country or a (negative) representation of a non-democratic country.

\section{STUDY 3}

A third study was conducted in order to specify to what extent the national character of a population is used to account for a given situation in a country. Study 2 showed that subjects take into account the national character especially in democratic contexts, indicating that the characteristics of the inhabitants should also be used to explain the functioning of democratic countries. In authoritarian contexts, however, the information on the government is more important than the national character information, so that subjects should attribute responsibility of the functioning of authoritarian states to governments rather than to its population. This hypothesis was tested in Study 3.

\section{Method}

\section{Subjects}

One hundred and twenty-six students of political science and international relations participated in the study, mean age was 21 years. Subjects were randomly assigned to the four experimental conditions.

\section{Stimulus Materials and Procedure}

The study was carried out in March 1996. A traditional paper and pencil questionnaire was used. In order to avoid specific effects of representations of human rights, subjects were not informed that they were participating in a study on human rights, but were told that the questionnaire was designed to investigate general issues of 'life in society'. The vignette method was again employed, each subject reading a oneparagraph vignette describing either the population or the government. The text on 
the type of government was identical to the one used in Study 1. The description of the inhabitants however contained only a reference to the conflict resolution behaviour of the inhabitants (Discussion versus Clashes).

\section{Dependent Measures}

The study was designed to investigate responsibility issues as well as the perceived content of democratic and non-democratic national characteristics. Here however we will only report results concerning the perceived responsibility of inhabitants and the government. As shown in Study 1, subjects readily infer the human rights situation on the basis of the political and the national character information. In this study, subjects were asked to evaluate to what extent (a) the ideology of the government and (b) the mentality of the inhabitants could explain the general situation in the country. Scales ranged from 1 (not at all) to 7 (yes absolutely).

\section{Results}

A MANOVA was performed with the two causal items as repeated measures and the two experimental variables (positivity/negativity and government/population) as between-subjects factors. The two experimental conditions using the population information induced a higher overall responsibility for the general situation of the country than the two government conditions, $F(1,122)=6.2 ; p<0.05$. No other between-subjects effect was significant.

The overall within-subjects responsibility effect (inhabitants versus government) was not significant, $F(1,122)=2.6$; n.s. However the interactions between responsibility and the two independent factors were both significant (positivity/negativity: $F(1,122)=35.3 ; p<0.001$ and government/population: $F(1,122)=6.0 ; p<0.05)$. Subjects attributed more responsibility to the inhabitants $(M=5.74)$ than to the government $(M=5.01)$ when the descriptions were positive, $F(1,122=8.8 ; p<0.01$, and more to the government $(M=6.11)$ than to the inhabitants $(M=4.84)$ when the descriptions were negative, $F(1,122)=27.4 ; p<0.001$. When subjects read descriptions of the population, no differences appeared between the two levels of responsibility, $M=5.58$ and 5.71 respectively, $F(1,122)<1$, whereas subjects in the two government conditions attributed less responsibility to the inhabitants $(M=4.86)$

Table 5. Attribution of responsibility for the general situation in a country, according to the experimental conditions for Study 3

\begin{tabular}{lcccccccc}
\hline & \multicolumn{4}{c}{ Positive } & \multicolumn{4}{c}{ Negative } \\
& $\begin{array}{c}\text { Democratic } \\
\text { government }\end{array}$ & \multicolumn{2}{c}{ Discussing } & \multicolumn{2}{c}{$\begin{array}{c}\text { Authoritarian } \\
\text { population }\end{array}$} & \multicolumn{2}{c}{ Clashing } \\
& $M$ & Sovernment & \multicolumn{2}{c}{ population } \\
& & $M$ & S.D. & $M$ & S.D. & $M$ & S.D. \\
\hline $\begin{array}{l}\text { Ideology of the } \\
\begin{array}{c}\text { government } \\
\text { Mentality of the } \\
\text { inhabitants }\end{array}\end{array}$ & 5.87 & 1.28 & 5.15 & 1.44 & 6.21 & 1.24 & 6.00 & 1.41 \\
\hline
\end{tabular}

Note. Scales: 1 , not at all responsible; 7 , totally responsible. 
than to the government $(M=5.54), F(1,122)=7.1 ; p<0.01$. Finally the interaction between the within and the two crossed independent factors was significant, $F(1,122)=4.3 ; p<0.05$. In the authoritarian government condition, subjects attributed more responsibility to the government, $F(1,122)=37.0 ; p<0.001$, whereas in the positive population condition the inverse was observed, $F(1,122)=5.8 ; p<0.05$. The differences in the two other conditions did not reach a conventional level of statistical significance $(p>0.05)$.

\section{Discussion}

The results confirm the hypothesis that a democratic population is seen as more responsible for the general national situation than a democratic government. Subjects' explanations of the situation in authoritarian systems, however, stress more the features of the government. Our results offer clear support for the hypothesis of a differentiation between explanations of human rights' respect and, more broadly speaking, the political situation in positively and negatively perceived national contexts. In a negative context subjects attributed the responsibility for the situation more to the government than to the inhabitants, whereas in a positive context they explained the favourable political situation with the characteristics of the inhabitants rather than with the political system.

\section{GENERAL DISCUSSION}

The results of our studies provide evidence relevant to an understanding of the role and importance attributed - by people living in a democracy - to democratic and non-democratic populations and governments in political judgements of different national states. In Study 1, subjects drew similar inferences from national contexts either described as democratic or characterized by orderly and discussing inhabitants. Likewise no differences were found between judgements on countries with authoritarian governments and national states described by their disorderly and clashing inhabitants. Results of Study 2 showed that judgements on a democracy are dependent on the representation people have of the population forming this democracy. Thus, the representation of respect of human rights is considerably lower when a democratic description is accompanied by a negative national character than when discussing people living in a democracy.

Moreover, the first two studies showed that people infer attitudes of political involvement, in the form of opposition to human rights' violations, to members of a national population not only on the basis of a description of the characteristics of the inhabitants, but also as a function of the political system of the country. In national contexts where subjects inferred human rights' violations, the inhabitants were seen as accepting these violations more than members of populations in countries that supposedly respect human rights. In democratic contexts this group inference process occurs as a function of perceived respect of human rights' violations. In authoritarian contexts, however, the correspondent inference is unrelated to the perceived level of human rights' respect. This result suggests that subjects differentiate democracies with 
regard to the political involvement of their inhabitants, but view the unfavourable human rights situation in non-democratic contexts as being independent of the political commitment of their populations. This may suggest that non-democratic populations are seen as being unable to exert any influence on the situation of the country they are living in.

The third study, by demonstrating the different weight subjects give to the responsibility of the inhabitants depending on the political system, confirms this finding. In a democratic country, compared to an authoritarian one, the mentality of the inhabitants was considered more responsible for the general situation than the ideology of the government. The reverse is true for an authoritarian context. Thus it seems that subjects account for positively perceived national situations with positive national stereotypes, whereas in negatively perceived national contexts the role of the government is given more weight.

The role of non-democratic populations in the representation and explanation of national states is characterized by two aspects that need to be articulated: on the one hand people judge the government as more responsible for the situation than the inhabitants, but infer at the same time population attitudes of political passivity. It thus seems that the authoritarian government is not seen as representative of its population, while at the same time the government's negative characteristics are reflected by the inferred political attitudes of the inhabitants. These findings suggest that both categories, the non-democratic population and the government, are held responsible for the unfavourably perceived situation, albeit in a different manner. The function and content of characteristics attributed to different national and cultural groups in the explanation of global inequality calls for future research (Olson, 1997).

Finally one should note that our argument does not deny the impact of the political and social system on characteristics shared by members of a national state. The political culture in a given country leaves its mark on human relations, and is reflected in its own way by national stereotypes. In our view the origin of national stereotypes is closely related to the representation of the political system in different national contexts. This may be especially true for countries about which people have only elementary knowledge concerning their political situation and functioning.

\section{CONCLUSION}

The representation of a human rights situation in a national context is easily constructed on the basis of information pertaining to the political system of a country, but also from stereotypical characteristics of the inhabitants. This finding strongly suggests that in the realm of human rights, as well as for other political judgements on national states, subjects associate and establish a parallel between the political organization of a national state and its population.

More generally people would infer attributes of group members not only as a function of a group's decision or outcome (Allison \& Messick, 1985, 1987; Allison, Worth, \& Campbell King, 1990), but also on the basis of a representation of the decision rules in effect in the group. Thus we suggest that a representation of a group's decision-making process itself (democratic versus non-democratic) is used by people 
as a social inference heuristic to judge group members' characteristics. However, representations of group decision making are in part dependent on liberal-democratic ideology. It would therefore be appropriate to consider the perception of authoritarian versus democratic decision making more as a consequence of lay theories about the group rather than as more or less accurate perceptions of the decisionmaking mechanisms.

One of these lay theories is grounded on philosophical essentialism. Our results provide indirect evidence for the assumption that people share lay political theories based on a essentialistic vision (Rothbart \& Taylor, 1992; Yzerbyt, Rocher, \& Schadron, 1997) of the democratic citizen. First, the clear polarization between democratic and non-democratic populations supports this argument. Secondly, the fact that people consider that a certain type of individual is required for the good functioning of a democratic society indicates that this view of the person is so pervasive that it is used as a universal standard by which all peoples of the world are judged and evaluated. When human rights violations occur, or when a population is full of dissent and conflict, many people may reason that such societies deny and pervert the 'true' inner nature of the individual. Therefore people may hold structural forces outside the person responsible for the unfavourable situation. Democracy should thus not be considered the natural consequence of the true human nature, as advocated by Fukuyama (1992), but rather as a result of historical, cultural and economic factors giving rise to inner workings of the society that finally may lead to some form of democracy.

The often observed passivity and disengagement of westerners concerning human rights events is quite troubling and, in a certain sense, contrary to the broad acceptance of human rights across political and ideological borders. One possible explanation is that people, at least those living in a context supposedly respecting human rights, adopt essentialistic explanations of democratic functioning and human rights' respect. These would be based on stable and inalterable characteristics of the members of democratic populations. Nowadays democracy is not merely a political issue, but also, and maybe first of all, a representational and ideological one. Democracy represents a value system which transcends many aspects of social life (Moscovici, 1992), beginning with a democratic individual necessary for the construction of a democratic society. By emphasizing the positive characteristics of the inhabitants of democratic countries, the use of human rights can thus also be seen as a protection and enhancement of one's own democratic identity.

\section{REFERENCES}

Allison, S. T., \& Messick, D. M. (1985). The group attribution error. Journal of Experimental Social Psychology, 21, 563-579.

Allison, S. T., \& Messick, D. M. (1987). From individual inputs to group outputs, and back again. Group processes and inferences about members. In C. Hendrick (Ed.), Review of personality and social psychology: Group processes (Vol. 8, pp. 111-143). Newbury Park, CA: Sage.

Allison, S. T., Worth, L. T., \& Campbell King, M. W. (1990). Group decisions as social inference heuristics. Journal of Personality and Social Psychology, 58, 801-811.

Augoustinos, M., \& Walker, I. (1995). Social cognition: An integrated introduction. London: Sage Publications. 
Benhabib, S. (Ed.) (1996). Democracy and difference: Contesting the boundaries of the political. Princeton, NJ: Princeton University Press.

Billig, M. (1991). Ideology and opinions: Studies in rhetorical psychology. London: Sage Publications.

Bond, M. H. (1988). Finding universal dimensions of individual variation in multicultural studies of values: The Rokeach and Chinese value surveys. Journal of Personality and Social Psychology, 55, 1009-1015.

Clémence, A., \& Doise, W. (1995). La représentation sociale de la justice: Une approche des droits dans la pensée ordinaire. Année Sociologique, 45, 371-400.

Clémence, A., Doise, W., De Rosa, A. M., \& Gonzalez, L. (1995). La représentation sociale des droits de l'homme: Une recherche internationale sur l'éténdue et les limites de l'universalité. Journal International de Pychologie, 30, 181-212.

Diaz-Veizadez, J., Widaman, K. F., Little, T. D., \& Gibbs, K. W. (1995). The measurement and structure of human rights attitude. Journal of Social Psychology, 135, 313-328.

Doise, W., \& Herrera, M. (1994). Déclaration universelle et représentations sociales des droits de l'homme: Une étude à Genève. Revue Internationale de Psychologie Sociale, 7, 85-105.

Doise, W., Clémence, A., \& Lorenzi-Cioldi, F. (1993). The quantitative analysis of social representations. Hemel Hempstead: Harvester Wheatsheaf.

Doise, W., Spini, D., Jesuino, J. C., Ng, S. H., \& Emler, N. (1994). Values and perceived conflicts in the social representations of human rights: Feasibility of a cross-national study. Swiss Journal of Psychology, 53, 240-251.

Dreben, E., Fiske, S., \& Hastie, R. (1979). The independence of evaluative and item information: Impression and recall order effects in behavior-based impression formation. Journal of Personality and Social Psychology, 37, 1758-1768.

Feagin, J. R. (1972). Poverty: We still believe that God helps those who help themselves. Psychology Today, 6, 101-129.

Fukuyama, F. (1992). The end of history and the last man. New York, Toronto: Free Press.

Guimond, S., Begin, G., \& Palmer, D. (1989). Education and causal attributions: The development of 'person-blame' and 'system-blame' ideology. Social Psychology Quarterly, 52, $126-140$.

Hewstone, M. (1989). Causal attribution. London: Basil Blackwell.

Humana, C. (1992). World human rights guide (3rd ed.). Oxford, New York: Oxford University Press.

Madiot, Y. (1991). Droits de l'homme. Paris: Masson.

Martijn, C., Spears, R., Van der Pligt, J., \& Jakobs, E. (1992). Negativity and positivity effects in person perception and inference: Ability versus morality. European Journal of Social Psychology, 22, 453-464.

Moghaddam, F. M., \& Vuksanovic, V. (1990). Attitudes and behavior toward human rights across different contexts: The role of right-wing authoritarism, political ideology, and religiosity. International Journal of Psychology, 25, 455-474.

Moscovici, S. (1976). La psychanalyse, son image et son public (2nd ed.). Paris: Presses Universitaires de France.

Moscovici, S. (1984). The phenomenon of social representations. In R. M. Farr, \& S. Moscovici (Eds), Social representations (pp. 3-70). Cambridge: Cambridge University Press.

Moscovici, S., \& Hewstone, M. (1984). De la science au sens commun. In S. Moscovici (Ed.), Psychologie sociale (pp.539-566). Paris: Presses Universitaires de France.

Moscovici, S. (1992). La démocratie et rien d'autre. Le genre humain, 26, 31-47.

Olson, J. T. (1997). Perceptions of global inequality: A call for research. Social Justice Research, 10, 39-62.

Rothbart, M., \& Taylor, M. (1992). Category labels and social reality: Do we view social categories as natural kinds? In G. Semin, \& K. Fiedler (Eds), Language, interaction and social cognition (pp. 11-36). London: Sage.

Skowronski, J., \& Carlston, D. (1987). Social judgment and social memory: The role of cue diagnosticity in negativity, positivity and extremity biases. Journal of Personality and Social Psychology, 50, 131-142.

Skowronski, J., \& Carlston, D. (1992). Caught in the act: When impressions on highly diagnostic behaviours are resistant to contradiction. European Journal of Social Psychology, 22, 435-452. 
Stainton-Rogers, R., \& Kitzinger, C. (1995). A decalogue of human rights: What happens when you let the people speak. Social Science Information, 34, 87-106.

Van der Pligt, J., \& Eiser, J. (1980). Negativity and descriptive extremity in impression formation. European Journal of Social Psychology, 10, 415-419.

Wagner, W., Elejabarrieta, F., \& Lahnsteiner, I. (1995). How the sperm dominates the ovum: objectification by metaphor in the social representation of conception. European Journal of Social Psychology, 25, 671-688.

Wish, M., Deutsch, M., \& Biener, L. (1970). Differences in conceptual structures of nations: An exploratory study. Journal of Personality and Social Psychology, 16, 361-373.

Yzerbyt, V., Rocher, S., \& Schadron, G. (1997). Stereotypes as explanations: A subjective essentialistic view of group perception. In R. Spears, P. Oakes, N. Ellemers, \& S. Haslam (Eds), The social psychology of stereotyping and group life (pp.20-50). Oxford, U.K. and Cambridge, U.S.A.: Blackwell Publishers. 